\title{
Angelika Czajkowska
}

Instytut Kultury

Wydział Zarządzania i Komunikacji Społecznej

Uniwersytet Jagielloński

\section{TRANSHUMANIZM - PRZYSZŁOŚĆ CZY ZAGŁADA NASZEJ CYWILIZACJI?}

Abstract

\section{TRANSHUMANISM - FUTURE OR DESTRUCTION OF OUR CIVILIZATION?}

Transhumanism has a great influence on the evolution of our society. It is defined as an ideology that perceives constant changes in a human being over the years. They are determined mainly by the unavoidable development of technology affecting i.a. creation of the first cyborgs or postmen. Transhumanism is also perceived in the use of various prostheses or implants as well as in wearable technologies and 3D printing. The aim of the study is to present the concept of transhumanism and its development, as well as to get to know the opinions of both scientists and respondents about this phenomenon. Their answers are not unambiguous, therefore in this article the author will strive to answer the question whether transhumanism is the future or perhaps the destruction of our civilization. The researcher used both qualitative data (analysis of existing data) and quantitative data (conducting a survey among respondents).

Key words: transhumanism, world development, future, society

\section{Wprowadzenie}

Przełom XX i XXI wieku wiązał się z rozwojem technologii informacyjnych i cyfrowych. Proces ten wpłynął także na społeczeństwo, a tym samym na kulturę. Ewolucji uległ również język, jakim posługują się ludzie, a także ich zachowanie oraz styl życia. Bardzo popularne jest wykorzystanie sieci Internet. Dzięki niej można pozyskiwać potrzebne informacje, a także nawiązywać relacje z innymi. W konsekwencji wszechobecna technologia jest coraz bliżej użytkowników, którzy często nie wyobrażają sobie bez niej życia i nałogowo korzystają z urządzeń elektronicznych, 
takich jak m.in. smartfony czy laptopy ${ }^{1}$. Pytanie, które wiąże się z nieuniknionym rozwojem transhumanizmu, dotyczy jego perspektyw - czy stanie się on przyszłością, a może zagładą naszej cywilizacji?

\section{Definicja oraz geneza transhumanizmu}

Transhumanizm określa się także jako zjawisko H+ (od human plus) i postrzega zarówno jako ideologię, światopogląd, jak i teorię społeczno-polityczną, podkreślającą zmiany, które z biegiem lat zachodzą w istocie ludzkiej. „Transhumanizm widzi człowieka jako plastyczne dzieło ewolucji, które nieustannie zmieniało się w czasie na przestrzeni ostatnich tysięcy lat"2. Koncepcja ta pomimo pozorów jej nowoczesności sięga czasów oświecenia. Jej istnienie w tamtym okresie podkreślali m.in. najważniejsi dziś przedstawiciele tego nurtu, czyli Max More oraz Nick Bostrom. Transhumanizm postrzega jednostkę nie jako osobę ludzką, lecz jako doskonalący się twór, dbający o zaspokojenie swoich potrzeb. Według naukowców ewolucja ta zamieni go najpierw w transczłowieka, a następnie postczłowieka ${ }^{3}$.

Prezentowana ideologia nawiązuje również do wielu zasad humanizmu, do szacunku dla rozumu i nauki oraz konieczności ewolucji istoty ludzkiej, która rozwija różne dziedziny nauki, m.in neurobiologię, biotechnologię oraz nanotechnologię. Światopogląd ten nie uznaje także wiary w przyszłe życie, a od humanizmu odróżnia go rozpoznanie i przewidywanie przełomowych zmian w przyrodzie oraz życiu społecznym ${ }^{4}$. Zdaniem transhumanistów pełna transformacja człowieka będzie możliwa dopiero wtedy, gdy zostaną spełnione trzy istotne warunki: zapewnienie bezpieczeństwa gatunku i wykluczenie ryzyka jego wyginięcia, przeprowadzenie postępu technologicznego bez jakiejkolwiek kontroli, a także udostępnienie społeczeństwu technologii transhumanistycznej.

$\mathrm{Z}$ pojęciem transhumanizmu łączy się także wiele różnych mitów, m.in. mit racjonalności, równości, a także człowieczeństwa. Pierwszy z nich polega na racjonalnym wykorzystaniu środków takich jak nauka czy technologia, które pozwolą transhumanistom zostać postludźmi oraz dostosować się do coraz szybciej ewoluującego środowiska. Ich emocje zejdą na drugi plan i nie będą determinować godności człowieka. Mit równości nawiązuje do przekonania, że transhumaniści są wolni od społecznych nierówności oraz politycznej zależności. Według Anny

1 D. Gałuszka, G. Ptaszek, D. Żuchowska-Skiba, Wyzwania i dylematy humanistyki XXI wieku, [w:] ciż (red.), Technokultura: transhumanizm i sztuka cyfrowa, Libron, Kraków 2016, s. 12-14.

${ }^{2}$ K. Szymański, Transhumanizm w kontekście stanowisk historiozoficznych, [w:] D. Gałuszka, G. Ptaszek, D. Żuchowska-Skiba (red.), Technokultura..., s. 27.

3 Tamże, s. 27, 31.

${ }^{4}$ K. Szymański, Transhumanizm, „Kultura i Wartości” 2015, nr 13, s. 134.

${ }^{5}$ K. Szymański, Transhumanizm: utopia czy ekstropia?, „Studia nad Strukturą i Rozwojem Pojęć Filozoficznych" 2015, nr XXVII, s. 172. 
Cieślak jest to jednak nieprawda, ponieważ zaawansowana technologia wpływa na zwiększenie nadzoru nad obywatelami i nie wyklucza wszechobecnie występującej nędzy, patologii oraz przemocy. Ostatni mit dotyczy człowieczeństwa ewoluującego pod wpływem ciągle rozwijającej się technologii. Emocje i kultura od zawsze były kształtowane przez człowieka, który nie jest doskonały. Według transhumanistów prawdziwym człowiekiem zostanie dopiero postczłowiek, czyli samokreująca się jednostka niezniewolona czynnikami organicznymi i obojętna na działanie natury. Wykorzystanie zaawansowanej technologii będzie zatem niwelować wrażliwe istoty posiadające wysokie aspiracje ${ }^{6}$.

Naukowcy stworzyli już wiele cyborgów, które ingerują w pierwotny system biologiczny człowieka. Pierwszy z nich powstał w 1998 roku podczas realizacji projektu Cyborg 1.0. W tym czasie Kevin Warwick, profesor cybernetyki na Uniwersytecie Coventry w Wielkiej Brytanii, zdecydował się na wszczepienie chipa we własne przedramię, dzięki któremu mógł sterować oświetleniem, ogrzewaniem oraz drzwiami. Badacz nie poprzestał na jednym zabiegu i wziął udział także w kolejnej edycji projektu, Cyborg 2.0. Podczas operacji jego system nerwowy został podłączony do komputera, a do nerwu przyśrodkowego lewej ręki wszczepiono mu ponad sto elektrod ${ }^{7}$. Zabieg ten wykonano w 2002 roku i pozwolił on Warwickowi m.in. kontrolować elektryczny wózek inwalidzki za pomocą interfejsu neuronowego. Mógł on także wytworzyć sztuczne odczucie bodźców przez poszczególne elektrody w układzie nerwowym ${ }^{8}$.

\section{Wykorzystanie transhumanizmu w obecnych czasach}

Proces transhumanizmu przebiega bardzo powoli, lecz nieustannie zmienia sposób funkcjonowania jednostki w społeczeństwie. W obecnych czasach ludzie ingerują w biologię swoich ciał na przykład przez zastosowanie protez czy implantów. Dzięki współczesnej technologii wiele osób, które kiedyś uznawano za osoby niepełnosprawne, jest obecnie w pełni dysponowanych. Wykorzystuje się nie tylko protezy, lecz także popularne rozruszniki serca, dające drugie życie potrzebującym. Kolejnym krokiem w rozwoju naszej cywilizacji jest dążenie do nieśmiertelności, czyli utopii, która według wielu naukowców jest możliwa do osiągnięcia9.

Transhumanizm jest również obecny m.in. w: ${ }^{10}$

- druku 3D;

- urządzeniach mobilnych;

6 A. Cieślak, Golem czy postczłowiek? Transhumanizm z perspektywy nie-ludzkiej, „Acta Humana" 2013, nr 4 (1), s. 95-108.

7 D. Gałuszka, G. Ptaszek, D. Żuchowska-Skiba (red.), Wyzwania i dylematy..., dz. cyt., s. 14-15.

${ }^{8}$ Zob. http://www.kevinwarwick.com/project-cyborg-2-0/ (dostęp: 3.12.2017).

${ }^{9}$ K. Szymański, Transhumanizm, dz. cyt., s. 133-134.

${ }^{10}$ L. Kopciewicz, Cyborgizacja-emancypacja? Kulturowe wyobrażenia techniki i postępu w czasach posthumanizmu, „Teraźniejszość - Człowiek - Edukacja” 2016, t. 19, nr 2, s. 148-151. 
- technologiach ubieralnych;

- internecie przedmiotów;

- holograficznej teleobecności.

Druk 3D nie jest najnowszym wynalazkiem, z biegiem czasu jednak jego wykorzystanie staje się coraz bardziej powszechne. Obecnie na zakup drukarki 3D może sobie pozwolić niemal każdy, a popularność drukowania w tej technologii przyczyni się do samowystarczalności społeczeństwa. Nawet osoba niepełnosprawna będzie mogła w prosty sposób wydrukować protezę czy inne urządzenie wspomagające jej życie. Jest to zdecydowanie rewolucyjny proces, który w szybki i tani sposób usprawni funkcjonowanie wielu poszkodowanych osób.

Wykorzystanie urządzeń mobilnych również wpływa na rozwój transhumanizmu. Coraz częściej społeczeństwo nie wyobraża sobie życia bez tabletów czy smartfonów. Dzięki nim użytkownik może w łatwy sposób dotrzeć o określonej godzinie w dane miejsce, a także być w kontakcie ze wszystkimi osobami bez względu na swoją pierwotną lokalizację. Urządzenia te wykorzystują Internet przedmiotów i są „wyposażone w sensory, z funkcją lokalizacji, "wrażliwe« na kontekst, mogące pośrednio albo bezpośrednio gromadzić, przetwarzać lub wymieniać dane za pośrednictwem sieci Internet"11.

Duży potencjał niosą w sobie także technologie ubieralne. Wiele osób posiada już smartwatche, które są nie tylko zwykłymi zegarkami, lecz także urządzeniami umożliwiającymi sprawdzenie pulsu, liczby wykonanych kroków czy nieodebranych połączeń telefonicznych. Technologie ubieralne są także wykorzystywane przy produkcji słuchawek bezprzewodowych, biżuterii, opasek oraz obroży dla psów. Posiadają o wiele więcej funkcji niż ich tradycyjne odpowiedniki i mogą na przykład wysyłać komunikaty z telefonów użytkowników czy wyświetlać swoją aktualną lokalizację. Warto także zauważyć, że rynek technologii ubieralnych cały czas się rozwija i poszukuje nowych rozwiązań ułatwiających wykonywanie codziennych czynności ${ }^{12}$.

Kolejnym obszarem, w którym dostrzega się transhumanizm, jest holograficzna teleobecność. $\mathrm{Na}$ jej rozwój wpłynęło udoskonalenie projektorów, które wyświetlają realistyczne trójwymiarowe obrazy w kilku miejscach jednocześnie. Technologia ta znajdzie zastosowanie w wielu obszarach, choćby w edukacji. Dzięki niej będzie można przeprowadzić cyfrową prezentację eksperymentów naukowych, symulację miejsc, a także zdalne nauczanie bez fizycznej obecności w klasie zarówno nauczyciela, jak i uczniów ${ }^{13}$.

Istotne wydarzenie związane $\mathrm{z}$ rozwojem transhumanizu odbyło się $\mathrm{w}$ październiku 2017 roku, kiedy robot humanoidalny po raz pierwszy w historii świata otrzymał obywatelstwo. Nazywa się Sophia i podczas światowego forum Future

11 Tamże, s. 149-150.

${ }_{12}$ Zob.http://technologicznie.pl/uroda/wearables-czyli-urzadzenia-ubieralne-krotki-przeglad/ (dostęp: 3.12.2017).

${ }^{13}$ L. Kopciewicz, Cyborgizacja-emancypacja?..., dz. cyt., s. 51. 
Investment Initiative zrobił tak duże wrażenie na uczestnikach, że władze Arabii Saudyjskiej mianowały go swoim obywatelem ${ }^{14}$. Jest to ważny moment dla naszego społeczeństwa, ponieważ właśnie w tym dniu Sophia została potraktowana jak człowiek, pomimo że nie jest istotą ludzką, a inteligentnym urządzeniem automatycznie wykonującym zadania.

\section{Przyszłość oraz zagrożenia wynikające z rozwoju transhumanizmu}

Według niektórych naukowców ludzie w przyszłości jeszcze bardziej wyjdą poza swoje biologiczne możliwości i będą wykorzystywać znane im urządzenia w zupełnie inny sposób. Na przykład telefony komórkowe zostaną ukryte w ubraniach lub umieszczone na dłoniach, a komputery będą współdziałać z użytkownikami, pomagając im wykonać trudniejsze zadania. Urządzenia staną się bardziej intuicyjne, przez co praca z ich użyciem będzie szybsza oraz przyjemniejsza. Technologia wszczepiania chipów, którą zapoczątkowały projekty Cyborg 1.0 oraz Cyborg 2.0, także zostanie rozwinięta. Chipy będą informować m.in. o nieprawidłowym funkcjonowaniu organizmu, na przykład kiedy człowiek zje za dużo cukru bądź przetworzonej żywności. Pomogą w lepszym odżywianiu, a także w utrzymaniu prawidłowej sylwetki. Przygotują spersonalizowany trening i przekażą informacje o tym, jakie partie ciała należy szczególnie trenować. W konsekwencji chipy wpłyną na wydłużenie ludzkiego życia, ponieważ społeczeństwo będzie bardziej o siebie dbać i kontrolować stan swoich organizmów. Jest to z jednej strony bardzo optymistyczna, ale z drugiej przerażająca wizja przyszłości, w której każdy krok człowieka będzie kontrolowany i badany przez różnorodne urządzenia.

Zdaniem wielu badaczy rozwój transhumanizmu nie jest możliwością, a wręcz koniecznością, której nie można już powstrzymać ${ }^{15}$. Transhumanizm wpłynie pozytywnie na rozwój naukowo-techniczny, a przede wszystkim na ewolucję człowieka jako gatunku, ale ludzie muszą być także świadomi zagrożeń związanych $\mathrm{z}$ tą ideologią. Dotyczy to w szczególności wykorzystania broni biologicznej i nuklearnej oraz rozwoju sztucznej inteligencji. Jednakże według N. Bostroma niebezpieczeństwa te mogą w przyszłości w ogóle nie wystąpić, ponieważ postczłowiek prawdopodobnie będzie posiadał bardziej rozwiniętą moralność i dążył do prowadzenia spokojnego życia, a nie ciągłej walki ${ }^{16}$.

Oprócz optymistów wierzących w powodzenie rozwoju transhumanizmu wyróżnia się także grupę badaczy, którzy nie traktują tego zjawiska poważnie. Postrzegają je jako utopię, która nigdy nie zostanie zrealizowana. Przewidują jednak

${ }^{14}$ Zob. http://www.wirtualnemedia.pl/artykul/robot-sophia-otrzymuje-obywatelstwo-arabii-saudyjskiej (dostęp: 3.12.2017).

${ }_{15}$ Transhumanizm. Człowiek w świecie maszyn, reż. Philippe Borrel, Francja 2012.

${ }^{16}$ K. Szymański, Transhumanizm w kontekście stanowisk..., dz. cyt., s. 40. 
nieuniknione zmiany zachodzące w technologii oraz społeczeństwie. Według Dona Ihdego transhumanizm jest porównywany do „techno-fantasy szumu, który nosi znamiona magii” ${ }^{17}$. Jego ewolucja wiąże się z dużym wysiłkiem, a zapewnienie wszystkich wspomnianych w pracy warunków niezbędnych do transformacji człowieka jest trudne, a wręcz niemożliwe do wykonania ${ }^{18}$.

Jeżeli jednak rozwój transhumanizmu doprowadzi do powstania wielu cyborgów, to istoty ludzkie będą mogły funkcjonować w ich otoczeniu i czerpać korzyści ze wspólnej egzystencji. Ich życie może zostać np. przedłużone, a zdolności umysłu staną się większe ${ }^{19}$. Podczas dążenia do rozwoju transhumanizmu należy być jednak bardzo ostrożnym oraz cały czas kontrolować ten proces, aby nie zaczął on zmierzać w niepożądanym przez społeczeństwo kierunku.

\section{Prezentacja opinii badanych na temat transhumanizmu}

W celu dokonania pełnej analizy istoty transhumanizmu autorka przeprowadziła ankietę dotyczącą postrzegania tej ideologii wśród wąskiej grupy 30 respondentów różniących się płcią, wiekiem, a także poziomem wykształcenia. Ankieta została przygotowana oraz udostępniona online i miały do niej dostęp wszystkie osoby chcące wyrazić swoją opinię na temat transhumanizmu. Wyniki badań prezentują się następująco:

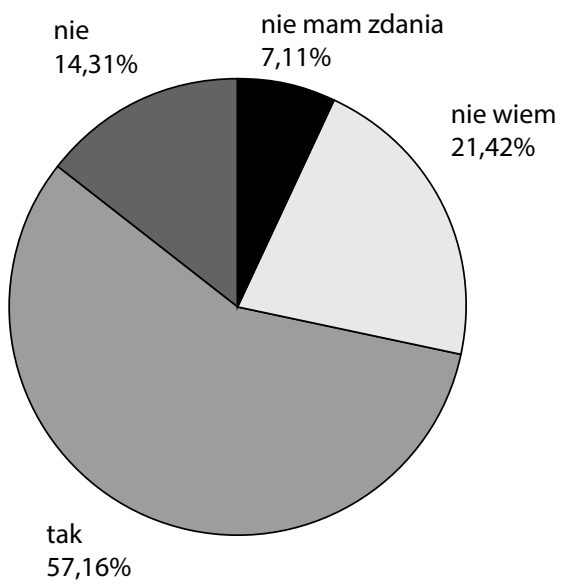

Rysunek 1. Czy według Pana/Pani naukowcy powinni rozwijać zjawisko transhumanizmu, a tym samym ingerować w obecne społeczeństwo?

Źródło: badania własne przeprowadzone w okresie 22.11-17.12.2017.

17 Cyt. za: K. Szymański, Transhumanizm: utopia..., dz. cyt., s. 172.

18 Tamże, s. 172-173.

${ }^{19}$ K. Szymański, Transhumanizm w kontekście stanowisk..., dz. cyt., s. 40. 
Ponad połowa respondentów (53,3\%) nie wiedziała, czym jest transhumanizm (osoby te nie odpowiadały na dalsze pytania zamieszczone w ankiecie), natomiast ci, którzy znali to pojęcie, definiowali je przede wszystkim jako udoskonalenie człowieka za pomocą technologii zwiększających możliwości ludzkiego ciała oraz umysłu. Jeden respondent zaznaczył także aspekt religijny, postrzegając transhumanizm jako „zabawę w Boga”. 85,7\% respondentów zauważa przejawy transhumanizmu w społeczeństwie głównie w medycynie (protezy, leki czy szczepionki), a także w filmach oraz książkach. Transhumanizm jest przez nich także postrzegany jako zjawisko użyteczne. W skali od 1 do 5 niewiele poniżej połowy badanych $(42,9 \%)$ ocenia go na 5; 35,7\% ankietowanych na 4 ; tylko $21,4 \%$ respondentów na 3 . Świadczy to o ich pozytywnym nastawieniu do badanej ideologii.

Według ponad połowy respondentów naukowcy powinni dalej rozwijać zjawisko transhumanizmu (rys. 2). 25\% badanych nie jest pewnych swoich odpowiedzi, a 14,3\% sprzeciwia się takim działaniom. Osoby, które odpowiedziały twierdząco, dostrzegały w transhumanizmie pozytywne cechy, takie jak ułatwienie ludzkiego życia, ulepszenie medycyny, niwelowanie konsekwencji wielu chorób oraz niepełnosprawności. Podkreślali oni jednak konieczność ustanowienia regulacji prawnych w tym zakresie.

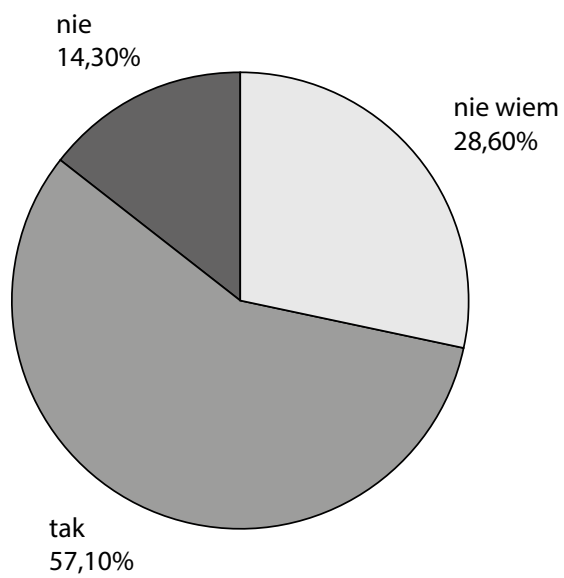

Rysunek 2. Czy w razie takiej możliwości zdecydowałby się Pan/Pani na wszczepienie elektronicznego implantu ułatwiającego Pana/Pani życie?

Źródło: badania własne przeprowadzone w okresie 22.11-17.12.2017.

Respondenci przeciwni rozwojowi transhumanizmu zwrócili uwagę m.in. na zaburzenie prywatności oraz bezpieczeństwa ludzi. Pomimo obaw aż $57,1 \%$ badanych zgodziłoby się na wszczepienie elektronicznego implantu, który ułatwiłby ich życie (rys. 3). Osoby niezdecydowane na taki zabieg stanowią $28,6 \%$ ankietowanych, a przeciwnych jest tylko 14,3\% badanych. Głównymi przesłankami, które 
zachęcają respondentów do podjęcia takiej decyzji, są możliwość wyboru odpowiedniego implantu, poddanie go testom oraz chęć dłuższego i łatwiejszego życia. Osoby negatywnie nastawione do tego typu zabiegów nie chcą być kontrolowane oraz obawiają się o swoje bezpieczeństwo.

Poniżej zaprezentowano opinie wszystkich badanych respondentów na temat przyszłości transhumanizmu. Ich zdaniem ludzie zostaną zastąpieni przez roboty w wielu czynnościach, np. podczas wykonywania prac fizycznych. Transhumanizm wpłynie także na wydłużenie ludzkiego życia, znalezienie sposobu na nieśmiertelność człowieka oraz powstanie postludzi. Jeden $\mathrm{z}$ badanych podkreślił konieczność uwzględnienia wielu problemów związanych $\mathrm{z}$ ewolucją tej ideologii. Są to m.in. problemy prawne, etyczne oraz polityczne. Zwrócono uwagę na czasochłonność przeprowadzenia tego procesu oraz fakt, że transhumanizm może kiedyś całkowicie zawładnąć człowieczeństwem.

Jak wyobraża sobie pan/pani przyszłość związaną z rozwojem transhumanizmu? ${ }^{20}$ :

- Roboty będą wykonywały większość prac fizycznych i zastąpią ludzi.

- Jak na razie temat jest mi obcy, także nie jestem w stanie wyobrazić sobie tego.

- Ludzie staną się nieśmiertelni, rozmnażanie zostanie ograniczone do minimum.

- Transhumanizm nie rozwinie się na szerszą skalę jeszcze przez bardzo długi czas, nawet jeśli będzie taka możliwość pod kątem dostępności technologii, wiąże się z nim bowiem za dużo problemów natury prawnej, etycznej czy nawet politycznej. Istnienie dużej liczby postludzi mogłoby np. doprowadzić do wyodrębnienia się innej rasy, postulującej (nie bez słuszności) swoją wyższość. Postludzie z pewnością spotykaliby się z dyskryminacją, przynajmniej w początkowych etapach rozwoju technologii. Według mnie rozwój transhumanizmu do takiego stopnia, by był on powszechnie akceptowanym faktem w społeczeństwie, to kwestia kilkunastu, może nawet kilkudziesięciu dekad.

- Nanoneurologia jest okazją, ale również może przyczynić się do zagłady ludzkości.

- Nie mam zdania.

- Na pewno z początku nie byłoby to łatwe, minie wiele lat, zanim dojdzie to do skutku.

- Mam nadzieję, że ta przyszłość sprawi, że życie będzie dłuższe i łatwiejsze.

- Technologia może zawładnąć człowieczeństwem.

- Każdy rozwój społeczeństwa jest dobry, jeśli służy on ludziom.

- Rozwój sztucznej inteligencji.

${ }^{20}$ Badania własne przeprowadzone w okresie 22.11-17.12.2017. 
- Transhumanizm przede wszystkim będzie rozwijał się w kierunku medycznym i militarnym. Są to najbardziej dochodowe dla tego przedsięwzięcia gałęzie.

Zdaniem $42,9 \%$ badanych postludzie w początkowej fazie rozwoju będą postrzegani głównie jako osoby zagrażające życiu ludzi, niewolnicy oraz specjaliści w określonej dziedzinie (rys. 3). Mogą także stać się przyjaciółmi człowieka, chociaż zdania respondentów dotyczące wspólnego życia ludzi oraz postludzi są podzielone: $50 \%$ badanych uważa, że mogą oni żyć razem, natomiast $50 \%$ sądzi, że jedna grupa zdecydowanie wykluczy istnienie drugiej.

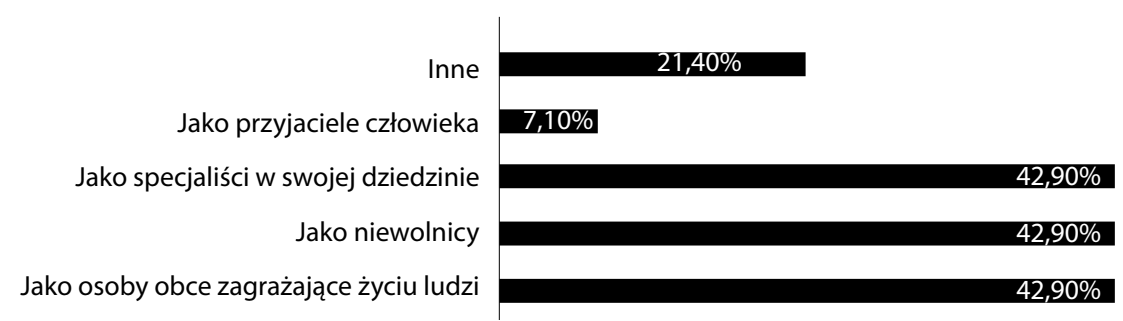

Rysunek 3. Jak Pana/Pani zdaniem będą postrzegani postludzie w początkowej fazie ich rozwoju na świecie?

Źródło: badania własne przeprowadzone w okresie 22.11-17.12.2017.

W badaniu wzięło udział 76,7\% mężczyzn oraz 23,3\% kobiet, głównie w przedziale wiekowym 21-39 lat (80\% badanych) oraz 40-56 lat (10\% respondentów). Zamieszkują oni miasta powyżej 500 tysięcy mieszkańców (66,7\% badanych) oraz miasta od 10 do 50 tysięcy mieszkańców (10\% ankietowanych), a także wsie (10\% respondentów). Większość respondentów studiuje (37,9\% badanych), posiada wykształcenie wyższe ( $31 \%$ ankietowanych) lub średnie (17,2\% respondentów).

Badanie przeprowadzone na wąskiej grupie respondentów prezentuje jedną $\mathrm{z}$ wielu tendencji, które można zaobserwować $\mathrm{w}$ społeczeństwie ${ }^{21}$.

\section{Zakończenie}

Rozwój transhumanizmu przypada na przełom XX i XXI wieku. Transhumanizm jest postrzegany jako światopogląd lub ideologia, która zauważa i podkreśla zmiany zachodzące w człowieku na przestrzeni lat. Istota ludzka stanowi natomiast ciągle doskonalący się, ewoluujący twór dążący do pełnego zaspokojenia swoich potrzeb.

21 Tamże. 
Zaawansowana technologia oraz jej powszechne wykorzystanie wpływają na ewolucję społeczeństwa i kierują je w stronę transhumanizmu. Elektroniczne urządzenia są codziennie używane przez wiele osób, które nie wyobrażają sobie bez nich funkcjonowania. Na rozwój tej ideologii wpływają także druk 3D, technologie ubieralne, Internet przedmiotów oraz holograficzna teleobecność.

Próbując odpowiedzieć na pytanie, czy transhumanizm jest szansą, czy zagrożeniem dla cywilizacji, należy zauważyć, że większość badanych osób w ogóle nie zna tego pojęcia. Respondenci, którzy potrafią je zdefiniować, widzą w nim jednak znaczący potencjał i szansę na dalszą ewolucję społeczeństwa. Podkreślają oni także konieczność zrównoważonego rozwoju, który nie będzie zagrażać ludzkiemu życiu. Badania zostały przeprowadzone na wąskiej grupie respondentów, jednak ich opinie dają obraz jednej z kilku tendencji dotyczących transhumanizmu i stanowią cenne źródło informacji w tym zakresie.

Zdanie naukowców na temat transhumanizmu jest bardzo zbliżone do odpowiedzi ankietowanych. Według nich życie ludzi z biegiem lat ulegnie zmianie i będzie ono jeszcze bardziej zależne od technologii. Powstaną np. smartfony wyświetlane na rękach użytkowników oraz chipy pomagające utrzymać ludziom w pełni zbilansowaną dietę, wydłużającą ich życie. Wielu badaczy przyjmuje pozytywną wizję przyszłości, w której człowiek będzie żyć w partnerskich stosunkach z postczłowiekiem, a jego rozwój nie wyeliminuje ludzkiego gatunku. Naukowcy zwracają jednak uwagę na inne niebezpieczeństwa zagrażające społeczeństwu, na przykład wykorzystanie broni biologicznej i nuklearnej, a także rozwój sztucznej inteligencji. Należy zatem dążyć do rozwoju technologii, ale także ciągle ją kontrolować, aby nie ewoluowała ona w niesprzyjający dla ludzkiego gatunku sposób.

Niektórzy badacze nie traktują jednakże transhumanizmu jako przełomowej ideologii, lecz postrzegają go jako utopię, która jest niemożliwa do osiągnięcia. Transhumanizm stanowi zatem bardzo tajemniczą koncepcję, której rozwój trudno przewidzieć. Warunkuje go wiele czynników, przez co odpowiedź na postawione pytanie badawcze nie jest jednoznaczna.

\section{Bibliografia}

Cieślak A., Golem czy postczłowiek? Transhumanizm z perspektywy nie-ludzkiej, „Acta Humana" 2013, nr 4 (1), s. 95-108.

Gałuszka D., Ptaszek G., Żuchowska-Skóra D., Wyzwania i dylematy humanistyki XXI wieku, [w:] ciż (red.), Technokultura: transhumanizm i sztuka cyfrowa, Libron, Kraków 2016, s. 9-21.

http://images.thestar.com/content/dam/thestar/news/world/2017/10/29/sophia-the-robotis-now-a-citizen-of-saudi-arabia/sophia_1.jpg.size-custom-crop.1086x0.jpg (dostęp: 3.12. 2017).

http://www.kevinwarwick.com/project-cyborg-2-0/ (dostęp: 3.12.2017). 
http://technologicznie.pl/uroda/wearables-czyli-urzadzenia-ubieralne-krotki-przeglad/ (dostęp: 3.12.2017).

http://www.wirtualnemedia.pl/artykul/robot-sophia-otrzymuje-obywatelstwo-arabii-saudyjskiej (dostęp: 3.12.2017).

Szymański K., Transhumanizm, „Kultura i Wartości” 2015, nr 13, s. 134-152.

Szymański K., Transhumanizm w kontekście stanowisk historiozoficznych, [w:] D. Gałuszka, G. Ptaszek, D. Żuchowska-Skóra (red.), Technokultura: transhumanizm i sztuka cyfrowa, Libron, Kraków 2016, s. 25-45.

Szymański K., Transhumanizm: utopia czy ekstropia?, „Studia nad Strukturą i Rozwojem Pojęć Filozoficznych" 2015, nr XXVII, s. 159-175.

Kopciewicz L. Cyborgizacja-emancypacja? Kulturowe wyobrażenia techniki i postępu w czasach posthumanizmu, „Teraźniejszość - Człowiek - Edukacja” 2016, t. 19, nr 2, s. 139-153.

Transhumanizm. Człowiek w świecie maszyn, reż. Philippe Borrel, Francja 2012. 